ISSN 1991- 8690

الترقيم الدولي ·

Website: http://jsci.utq.edu.iq

Email: utjsci@utq.edu.iq

\title{
Study on Dye-sensitized Solar Cells based on ZnO Nanorods and Graphene Enhanced P3HT as HTM
}

\author{
Samir Mahdi AbdulAlmohsin ${ }^{*} \quad$ Fouad Nimr Ajeel Shakir Abdul-Hussein Al-Saidi \\ College of Science - Department of Physics - Thi Qar University-Thi Qar, IRAQ \\ *Correspondence: smabdulalmoh@ualr.edu
}

\begin{abstract}
A quasi solid state dye-sensitized solar cells (DSSC) is fabricated using 1-propyl-3methylimidazolium iodide and Poly (3-Hexail Thiophene) P3HT, and P3HT-loading graphene (G) as the composite electrolyte. The electrolyte without added iodine is sandwiched between $\mathrm{ZnO}$ NW photo electrode both pristine and graphene enhanced P3HT (G-P3HT, $5 \%$ wt graphene) were used in solid state dye as Hole transport material draw a lot of attention due to easy fabrication, using P3HT-Graphene (P3HTI-graphene) nanocomposites were synthesized on FTO glass by solution process and employed as HTM to replace the conventionally used expensive Pt electrode, The solar cells based on vertical $\mathrm{ZnO}$ nanowire arrays by utilizing a mixture paste of LiI, PMII and solid iodine as electrolyte. The initial results showed the power conversion efficiency of $2.1 \%$. The cells with pristine and G-P3HT showed different performance. The power conversion efficiency was improved from 0.16 to $2.1 \mathrm{~mA}$ for G-P3HT solar cells. It exhibited increased power conversion efficiency from 0.87 to $2.1 \%$.
\end{abstract}

Keywords: Nanocomposite; graphene; organic elecronics; metal oxide semiconductor; solid state dye- sensitive solar cells.

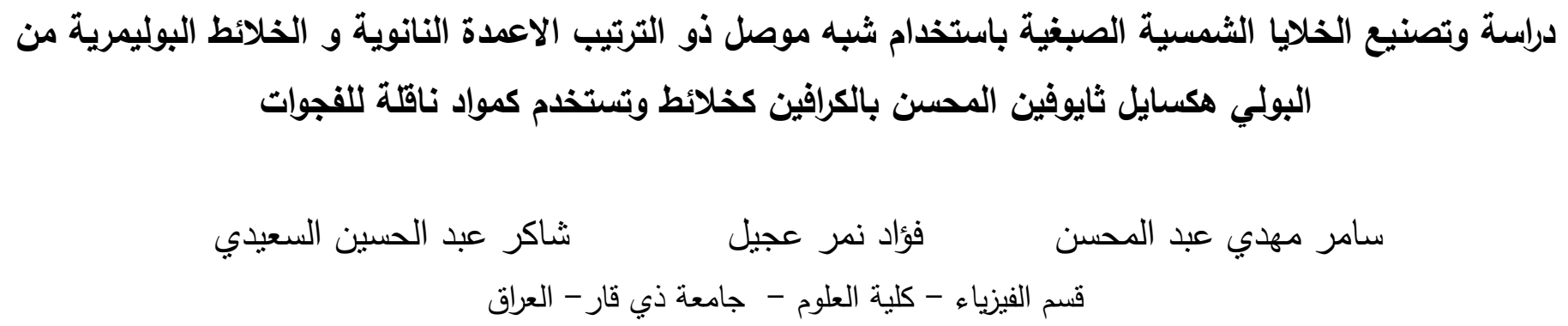

$\underline{\text { الخلاصة }}$

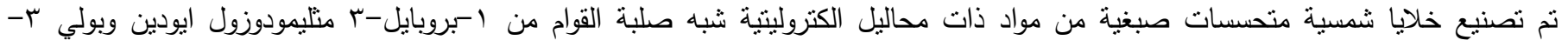

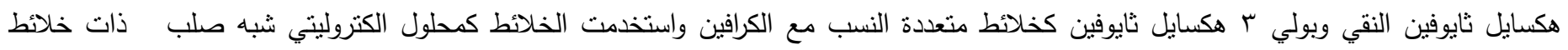
مختلفة النسب .تم دراسة وتصنيع خلايا شمسية بوجوداليود وباستخدام نسب مختلفة من اليود في تركيبة المحلول الالكتروليتي شبه الصلب ودراسة تاثير اليود

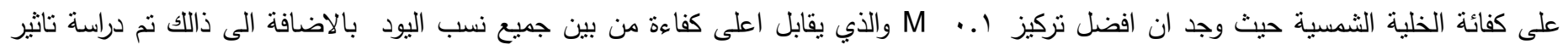
الكرافين على المادة الناقلة للفجوات المتمنلة بالبوليمر الموصل العضوي بولي بـانه هكسايل ثايوفين حيث وجد ان هناللك تحسن كبير وواضح بزيادة الكفائة

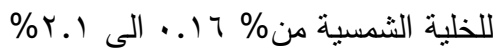


الكلمات المفتاحية: خلائط بوليمرية نانوية ،كرافين، الاككترونيات العضوية ، التراكيب النانويةلاكاسيد المعادن الثبه موصلة، الخلايا الثمسية الصبغية

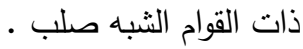

\section{Introduction}

Dye-sensitized solar cells (DSSCs) have attracted worldwide attention because of their low fabrication costs, promising light harvesting to energy conversion efficiency and environmental friendliness but it has shifted recently from base on liquid electrolytes to quasi solid-state dye ,because of the problems such as hermetic sealing of the cells, evaporation of liquids at high temperatures, permeation of water and oxygen molecules into the electrolyte especially due to the corrosive nature of iodine. Replacing the liquid of electrolyte with a solid or quasi solid electrolyte is to solve these problems. The high-energy conversion efficiency of dye-sensitized solar cells are accomplished through the use of highly porous semiconductor films coated with dye sensitizer as the working electrode [1]. O'Regan developed these dyesensitized solar cells consist of three main components: working electrode, electrolyte and a counter electrode. The working electrode is usually $\mathrm{TiO} 2$ coated with dye to absorb light and generate exitons. The electrolyte is a mixture of I-/I3- for transferring electrons from counter electrode to excited dyes. The counter electrode is coated with a catalyst film to promote electron transfer to the electrolyte through the reduction of tri-iodide I3[2]. They have the highest catalytic activity with the I3. However, due to their high cost, alternative materials are intensively studied such as carbon black [3] carbon nanotube [4] and conductive polymers [5]. Conducting polymers are promising candidates for DSSC or for solid-state dye sensitive solar cells counter electrodes because of their unique properties, including low cost, good conductivity, remarkable stability and good catalytic activity for I3- reduction [6]. Many conductive polymers (poly pyrrole, polyaniline, poly $(3,4-$ ethylenedioxythiophene), polythiophene) were investigated as materials for DSSC counter electrodes. P3HT is one of the most studied polymers because of its high conductivity and good topographic properties [7]. It is widely used in various applications such as super capacitors [8], field emission [9], sensors [10], dye-sensitized solar cells and Bulk hetrojunction solar cells. Deibel et al (2010) constructed P3HT films by dissolving $10 \mathrm{mg} / 1 \mathrm{ml}$ in chloroform and then affixed this polymer material to conductive glass, where it was used as hole transport materials. This study obtained high DSSC efficiency $\sim 7.73 \%$. This high solar cell performance is most likely due to an increase in counter electrode interfacial area. Serap Gunes [9] and Deibel et al (2010) used P3HT film as hole transport Materials on the top $\mathrm{TiO} 2$-dye conductive glass by spin coater deposition and used this as counter electrodes of a quasi solid-state DSSC. They obtained promising results with the highest efficiency $\sim 0.3 \%$. Direct polymer deposition on conductive glass should favor strong polymer bonding to conductive surfaces. This will facilitate electron transport from the conductive glass to polymer and improve DSSC performance where it so called solid-state dye sensitive solar cells. In this present work, we report the preparation of nanocomposite materials of P3HT-G films by spin coater, with and without graphene. The performance of P3HT-graphene and pristine $\mathrm{P} 3 \mathrm{HT}$ based on $\mathrm{ZnO}$ nanorods as a photo anode deposited on the top of FTO glass. The influence upon solar cell performance was analyzed by I-V characteristic under light and dark. The polymer structure was characterized by scanning electron microscopy (SEM).

\section{Experimental Details}

\section{A- Materials:}

\section{1- P3HT mix 5\% wt graphene films}

A Fluoride-doped TiN Oxide (FTO, sheet resistance $16 \Omega /$ sq) glass was used as the conducting substrate for both working and counter electrodes. P3HT use (Aldrich) $10 \mathrm{mg}$ and 5\% wt loading graphene dissolve them in $1 \mathrm{ml}$ chloroform then using a bath stirrer for 30 min to dispersing graphene with P3HT. Then, using spin coater 600 for $40 \mathrm{sec}$ to get very uniform thin films on FTO glass were used as the 
counter electrode and the $\mathrm{TiO}_{2}$ and, $\mathrm{ZnO}$ nanorods as working electrode, respectively.

\section{2- $\mathrm{ZnO}$ nanorods}

The most widely used fabrication methods to obtain $\mathrm{ZnO}$ nanorods by electrochemical method. $\mathrm{ZnO}$ nanorods on FTO glass substrates [11] are typically prepared by two steps, first step prepare $\mathrm{ZnO}$ thin film by electrochemical method using 0.05 M Zinc nitrate dissolve in (50:50) ethanol :DI water for 5 min applied voltage -2.5 volt using FTO glass as working electrode and $\mathrm{Au}$ wire as reference and counter electrode second step using zinc nitrate 0.01 $\mathrm{M}$ and hexamethaial amine $0.01 \mathrm{M}$ dissolve with $100 \mathrm{ml}$ water for at least $60 \mathrm{~min}$ then washed by DI water and dry it by polling with nitrogen gas to be ready for use.

3- Synthesis of graphene, P3HT, and P3HTgraphene Composites.

The graphene were purchased from cheap tube as nanoplates, and the surface area equal $500 \mathrm{~cm}^{2} / \mathrm{g}$ semimetal. The P3HT-graphene nanocomposite was prepared with $5 \%$ wt graphene by the weight of polymer.

\section{B- Solar cell fabrication:}

N719 ethanol solution was dipped on the as-prepared FTO glass/ZnO NW and dried naturally. Then, a mixture electrolyte (0.6 M $\quad$ 1-methyl-3 propoylimidazolium iodide $(\mathrm{PMII})+0.1 \mathrm{M} \mathrm{LiI}+2 \mathrm{~g} \mathrm{I})$ was dipped onto the surfaces of both FTO/ZnO NW/N719 and FTO/P3HT-graphene. The final devices were made by sandwiching the FTO glass/ZnO NW/N719/PMII and P3HT-graphene/FTO glasses as shown in Figure 7

\section{C- Structural analyses:}

Figure 1 shows the SEM images of $\mathrm{ZnO}$ nanorods, $\mathrm{ZnO}$ thin film and AZO films. The top view and cross section of as-grown $\mathrm{ZnO}$ Nanorods shows the hexagonal structure of individual nanowires vertically aligned on the substrate. The average diameter of the nanorods is $200-300 \mathrm{~nm}$ with a density of 20 nanorods per $\mu \mathrm{m}^{2}$.

\section{Results and Discussion}

In this section, we showed characterization of graphene, P3HT and the P3HT-graphene composites, as follows:

\section{1- Optical Properties of Materials}

The optical absorption spectrum of the poly (3HT) film was displayed from $200 \mathrm{~nm}$ to $1000 \mathrm{~nm}$ in Figure 2. The absorption range is from $450 \mathrm{~nm}$ to $650 \mathrm{~nm}$. It should be noted that the strong Terrestrial solar photons flux between $400 \mathrm{~nm}$ to $800 \mathrm{~nm}$ should be considered to be a primary factor influencing the photo induced carrier mechanism of a solar cell. The presence of P3HT in the solution is characterized by the absorption band between 350 to $600 \mathrm{~nm}$, with a peak at $450 \mathrm{~nm}$. It can be seen that the P3HT-graphene composite has almost the same absorption range and peak as that of the pure P3HT solution in the wavelength range from 350 to $600 \mathrm{~nm}$, except that the absorption peak of the P3HT-graphene composite is slightly broadened, and absorbs more strongly below 400nm and above $550 \mathrm{~nm}$. This should be caused by the absorption of graphene in the composite film. The absorption spectrum of the P3HT solution shows no significant change upon adding 5\% wt of graphene. This implies that in the P3HT-graphene composite, no significant ground-state interactions take place between the two materials, and hence, no charge transfer occurs in the ground state, which is consistent with the literature [12]. Figure 3 displays the optical absorption spectra of $\mathrm{ZnO} \mathrm{NW}$ on FTO, N719 in solution, and ZnO NW modified with N719 were measured and shown in Figure 3. The modified ZnO NW. The N719 in solution has a strong 2 absorption peaks are $423 \mathrm{~nm}, 515 \mathrm{~nm}$ and a number of small peaks in the visible range, which is similar to that reported in the literature [13]. The $\mathrm{ZnO}$ NW modified exhibits a strong increase in absorption around $515 \mathrm{~nm}$, which is attributed to the additional absorption of the N719 coating. Figure 4 presents the X-Ray diffraction (XRD) spectra of N719 on ZnO NW (black curve), and N719 on ITO glass (red), ITO glass (yellow) the peak at the centered at 2 theta $\sim 31.110$ and 36.130 are from ITO glass, and the strong peaks 2 theta $\sim 34.20$ is from the $\mathrm{ZnO}$ NW surface. XRD results explain that the final crystalline structure does not effect after modified by 
N719 and aggregation of N719 to ZnO NW surface introduce no change in crystalline structure of $\mathrm{ZnO}$ NW.

\section{2- Current density-Voltage Characteristic}

Based on P3HT and P3HT mix 5\% wt graphene for $\mathrm{ZnO}$ nanorod modified N719 as a working electrode explained in the figure 5 where the pristine $\mathrm{P} 3 \mathrm{HT}$, P3HT-G as HTM, as seen from the figures of I-V characteristic that P3HT-graphene better performance than pristine $\mathrm{P} 3 \mathrm{HT}$, due to graphene used to enrichment of P3HT and that will help decrease the internal resistivity. Furthermore, the performance of solar cells at $0.1 \mathrm{M}$ Iodine represent best PCE as we see from the Table 1,and Figure 6 the best efficiencies for the optimum condition which are $0.1 \mathrm{M}$ Iodine and P3HTGraphene with $\mathrm{ZnO}$ nanorods modified N719 represent most efficient solid-state dye sensitive solar cells. Figures 4,5 ,and 6 display I-V characteristic of the photovoltaic devices.

\section{Conclusions}

Recently, graphene, a single layer hexagonal lattice of carbon nanotube atoms, has recently emerged with conductive polymer for improving properties because graphene possesses a range of unusual properties therefore the efficiency increase for both designs when loading 5\% wt graphene with $\mathrm{P} 3 \mathrm{HT}$ as counter electrode (HTM), Table 1 shown increasing in efficiency and the efficiency for $\mathrm{ZnO}$ nanorod, as a working electrodes The better performance of solar cells with $0.1 \mathrm{M}$ iodine as a solid electrolyte and P3HTGraphene as HTM in solid-state dye sensitive solar cells less performance than pristine P3HT because P3HT-graphene provide an intrinsic energy barrier which effectively suppresses charges recombination and increases the electron life time. In addition the Iodine has high electrons provider to less electron lifetime.

\section{Acknowledgments}

We thank the Ministry of Higher Education and Scientific Research of Iraq for its support of scientific researches through the Iraqi Virtual Science Library (IVSL).

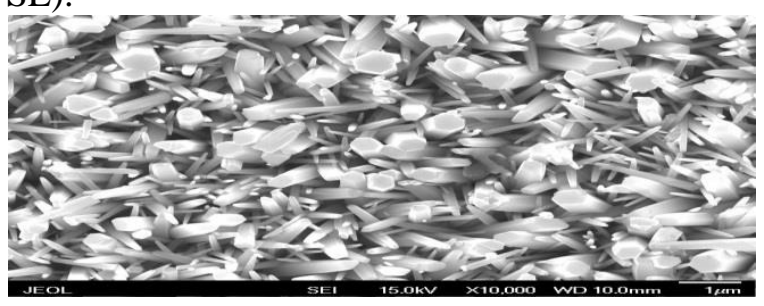

Figure 1: SEM images of $\mathrm{ZnO}$ nanorods.

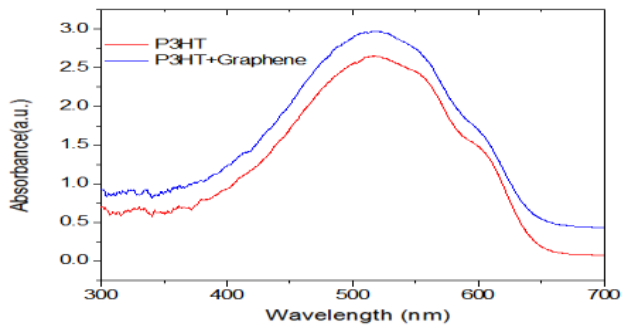

Figure 2: The optical absorption spectrum of the poly (3HT 5\% wt) in the UV-visible-NIR range.

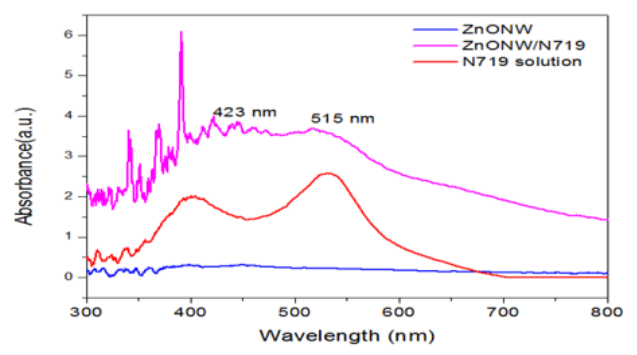

Figure 3: The Optical Absorption spectrum of ZnO NW, ZnO NW/N719, and N719 solution.

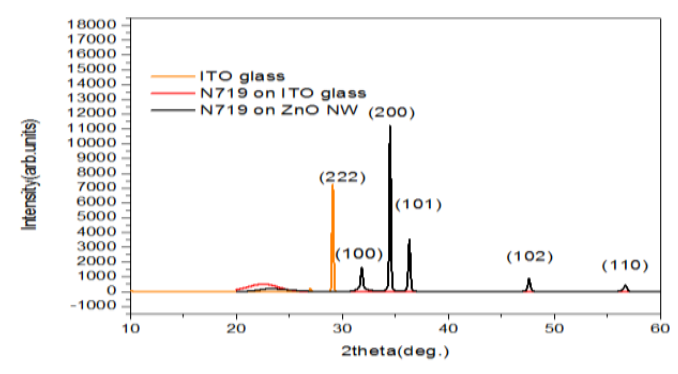

Figure 4: XRD spectrum of pristine N719 (red curve), N719 on ZnO NW arrays (black curve), and ITO (yellow).

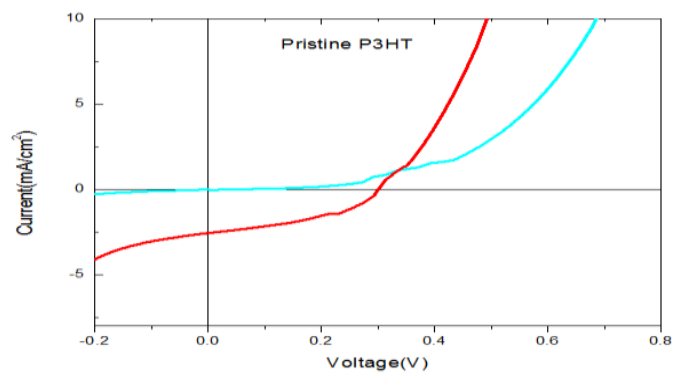

Figure 5: Current density vs. voltage measured on $\mathrm{P} 3 \mathrm{HT} / \mathrm{ZnO}$ nanowire arrays solid state dye for Pristine. 


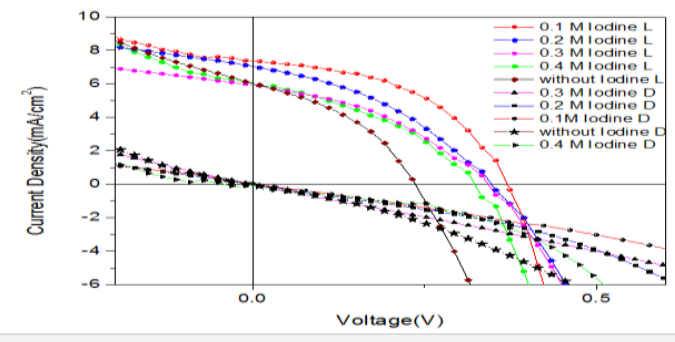

Figure 6: Current density vs. voltage measured on G-P3HT/ZnO nanowire arrays solid state dye with different loading of Iodine.

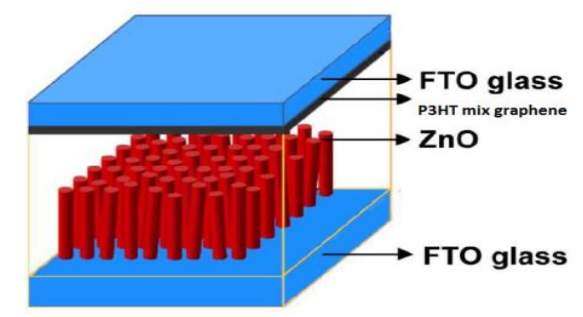

Figure 7: Schematic diagrams of the newstructure $\mathrm{ZnO}$ nanorod DSSC fabricate.

Table 1: I-V values for solid-state dye sensitive solar cells.

\begin{tabular}{|c|c|c|c|c|}
\hline Dye Sensitive solar Cell & $\mathbf{V}_{\text {oc }}$ & $\mathbf{I}_{\text {sc }}$ & FF & Efficiency \\
\hline Pristine P3HT & 0.3 & 1.77 & 0.58 & 0.311 \\
\hline $\begin{array}{c}\text { Nanocomposite P3HT-G } \\
\text { for 0.1 M of Iodine }\end{array}$ & 0.37 & 7.4 & 0.45 & 1.25 \\
\hline P3HT-G for 0.2 M Iodine & 0.347 & 7.03 & 0.36 & 0.9 \\
\hline P3HT-G for 0.3 M Iodine & 0.341 & 5.95 & 0.379 & 0.77 \\
\hline P3HT-G for 0.4 M Iodine & 0.322 & 6.03 & 0.378 & 0.73 \\
\hline P3HT-G without Iodine & 0.236 & 6 & 0.374 & 0.53 \\
\hline
\end{tabular}

\section{References}

[1] B. O'Regan and M. Gratzel, "A low-cost, highefficiency solar cell based on dye-sensitized colloidal TiO2 films," nature, vol. 353, pp. 737740, 1991.

[2] K. Keothongkham, S. Pimanpang, W. Maiaugree, S. Saekow, W. Jarernboon, and V. Amornkitbamrung, "Electrochemically deposited polypyrrole for dye-sensitized solar cell counter electrodes," International Journal of Photoenergy, vol. 2012, 2012.

[3] T. N. Murakami, S. Ito, Q. Wang, M. K. Nazeeruddin, T. Bessho, I. Cesar, P. Liska, R. Humphry-Baker, P. Comte, and P. t. Pechy, "Highly efficient dye-sensitized solar cells based on carbon black counter electrodes," Journal of the
Electrochemical Society, vol. 153, pp. A2255A2261, 2006.

[4] S. AbdulAlmohsin, M. Mohammed, Z. Li, M. A. Thomas, K. Y. Wu, and J. B. Cui, "Multi-walled carbon nanotubes as a new counter electrode for dye-sensitized solar cells," Journal of nanoscience and nanotechnology, vol. 12, pp. 2374-2379, 2012.

[5] S. M. M. a. M. S. AbdulAmohsin, M. Mohamed, "ZnO Nanowire/N719 Dye/Polythiophene-SWNT Nanocomposite Solid-state Dye Sensitized Solar Cells," Automation, Control and Intelligent Systems, vol. 3, pp. 12-17 2015.

[6] Z. Li, B. Ye, X. Hu, X. Ma, X. Zhang, and Y. Deng, "Facile electropolymerized-PANI as counter electrode for low cost dye-sensitized solar cell," Electrochemistry Communications, vol. 11, pp. 1768-1771, 2009.

[7] Y. Zhao, G. Yuan, P. Roche, and M. Leclerc, "A calorimetric study of the phase transitions in poly (3-hexylthiophene)," Polymer, vol. 36, pp. 22112214, 1995.

[8] E. Frackowiak, V. Khomenko, K. Jurewicz, K. Lota, and F. Beguin, "Supercapacitors based on conducting polymers/nanotubes composites," Journal of Power Sources, vol. 153, pp. 413-418, 2006.

[9] G. Lai, Z. Li, L. Cheng, and J. Peng, "Field Emission Characteristics of Conducting Polymer Films Conditioned by Electric Discharge," Journal of Materials Science and Technology, vol. 22, 2006.

[10] H. Bai and G. Shi, "Gas sensors based on conducting polymers," Sensors, vol. 7, pp. 267307, 2007.

[11] J. Cui and U. J. Gibson, "Enhanced nucleation, growth rate, and dopant incorporation in $\mathrm{ZnO}$ nanowires," The Journal of Physical Chemistry B, vol. 109, pp. 22074-22077, 2005.

[12] D. Yu, Y. Yang, M. Durstock, J.-B. Baek, and L. Dai, "Soluble P3HT-grafted graphene for efficient bilayerân ${ }^{\wedge}$ heterojunction photovoltaic devices," ACS nano, vol. 4, pp. 5633-5640, 2010.

[13] Q. Liu, Z. Liu, X. Zhang, L. Yang, N. Zhang, G. Pan, S. Yin, Y. Chen, and J. Wei, "Polymer photovoltaic cells based on solution-processable graphene and P3HT," Advanced Functional Materials, vol. 19, pp. 894-904, 2009. 